\title{
KEMAMPUAN KOMUNIKASI DAN PEMECAHAN MASALAH MATEMATIS MAHASISWA PENDIDIKAN GURU SEKOLAH DASAR MELALUI PEMBELAJARAN BERBASIS MASALAH
}

\author{
Karlimah (arli_karlimah@yahoo.com) \\ PGSD FIP Universitas Pendidikan Indonesia
}

\begin{abstract}
This experimental study was conducted to investigate students' mathematical communication and problem solving abilities by using problem based learning (PBL). The subjects of this study were 67 student teachers from a State University in Bandung. Instruments of this study were a mathematical communication test and a mathematical problem solving test. The data were analyzed by using one and two path ANOVA, Mann Whitney test and chi square test. The study found that: (1) Students' mathematical communication and problem solving abilities in PBL classroom were higher than those of students of conventional classroom; (2) The advantage of PBL were also supported by the findings that mathematical communication and problem solving abilities of students with low initial ability were higher in PBL classroom compared to those ofconventional classroom; (3) There was significant correlation between mathematical communication and problem solving abilities; (4) There were no interaction between teaching approaches and prior mathematics ability on students' mathematical communication and problem solving abilities.
\end{abstract}

Keywords: mathematical communication, mathematical problem solving, problem-based learning

Kemampuan komunikasi dan pemecahan masalah matematis merupakan dua kemampuan esensial yang harus dikembangkan pada siswa dan mahasiswa calon guru sesuai dengan Kurikulum Matematika SD, SMP, SMA tahun 2006, dan Kurikulum S1 PGSD tahun 2006. Pentingnya kepemilikan kemampuan pemecahan masalah matematis sudah dikemukakan Branca (dalam Sumarmo, 1994, 2006) yaitu: (1) kemampuan pemecahan masalah merupakan tujuan umum pembelajaran matematika, bahkan sebagai jantungnya matematika, (2) penyelesaian masalah yang meliputi metode, prosedur, strategi dalam pemecahan masalah merupakan proses inti dan utama dalam kurikulum matematika, dan (3) pemecahan masalah merupakan kemampuan dasar dalam belajar matematika.

Polya (Sumarmo, 1994) mendefinisikan pemecahan masalah sebagai suatu usaha untuk mencari jalan keluar dari suatu kesulitan untuk mencapai tujuan yang tidak dengan segera diperoleh. Lebih lanjut Polya (Sumarmo, 1994, 2006) mengemukakan langkah-langkah pemecahan masalah, yaitu: (1) memahami masalah yang meliputi mengidentifikasi unsur yang diketahui dan yang ditanyakan, mengidentifikasi kecukupan unsur, dan menyusun model matematika (2) menyusun rencana pemecahan, atau memilih strategi, (3) melaksanakan perhitungan atau menyelesaikan model matematis, dan (4) memeriksa kembali hasil yang diperoleh.

Pentingnya pengembangan kemampuan komunikasi matematis pada mahasiswa juga tersirat ketika mahasiswa melakukan proses memecahkan masalah matematis, misalnya ketika menggunakan konsep matematika dan merepresentasikan hasil pemecahan masalah. Dalam proses tersebut, pada dasarnya mereka melakukan kegiatan komunikasi matematis antara lain mentransformasikan informasi matematika, mengembangkan dan mengomunikasikan ide matematika, berbicara dan menulis tentang apa yang sedang dikerjakan, memikirkan dan 
mengklarifikasi ide-ide matematika mereka, berbicara kepada dan mendengarkan penjelasan teman lain, serta berbagi ide, strategi dan solusi.

Sumarmo (2002) mengidentifikasi indikator komunikasi matematik yang meliputi kemampuan: (1) Menghubungkan benda nyata, gambar, dan diagram ke dalam ide matematika; (2) Menjelaskan ide, situasi dan relasi matematik, secara lisan dan tulisan dengan benda nyata, gambar, grafik dan aljabar; (3) Menyatakan peristiwa sehari-hari dalam bahasa atau simbol matematika; (4) Mendengarkan, berdiskusi, dan menulis tentang matematika; (5) Membaca dengan pemahaman suatu presentasi matematika tertulis; (6) Membuat konjektur, menyusun argumen, merumuskan definisi dan generalisasi; (7) Menjelaskan dan membuat pertanyaan tentang matematika yang dipelajari.

Salah satu alternatif pembelajaran yang menghadapkan mahasiswa pada tantangan atau masalah adalah pembelajaran berbasis masalah. Duch, Groh, dan Allen (2001) mengemukakan Problem-Based Learning (PBL) atau Pembelajaran Berbasis Masalah (PBM) sebagai suatu pembelajaran yang melibatkan formulasi masalah, tujuan pembelajaran, dan penilaian yang saling berkaitan. Formulasi masalah merupakan bentuk masalah atau tantangan yang dihadapkan kepada mahasiswa. Boud dan Felleti (dalam Saptono, 2003) dan Suradijono, (2004) mengemukakan formulasi masalah dalam pembelajaran berbasis masalah hendaknya merupakan masalah dalam kehidupan sehari-hari yang disajikan dalam konteks yang relevan. Tujuan pembelajaran berkaitan dengan sesuatu yang harus dimiliki oleh mahasiswa setelah belajar, yaitu pengetahuan mengenai konten atau materi matematika, keterampilan atau kemampuan yang meliputi mengajukan pertanyaan, menyusun esai, mencari data, dan merepresentasi data serta mengomunikasikan hasil dan sikap yang menggambarkan kebiasaan berpikir kritis, aktif mendengar dan menjelaskan, serta menaruh perhatian terhadap argumentasi mahasiswa lain. Berkenaan dengan sikap atau aspek afektif lainnya, Akinsola (2008) mengemukakan bahwa dalam memecahkan masalah mahasiswa perlu memiliki motivasi yang tinggi dan perasaan tertekan atau perasaan cemas yang rendah. Penilaian dalam pemecahan masalah hendaknya relevan dengan tujuan yang ingin dicapai.

Beberapa studi tentang kemampuan matematis dilaporkan oleh Kusmini (2005), yang mengemukakan bahwa siswa kelas V SD dapat mengembangkan kecakapan matematika setelah belajar dengan PBM. Studi lain berkenaan dengan PBM adalah Nasrun (2008) yang menyatakan bahwa PBM dapat meningkatkan kemampuan menaksir pada penjumlahan bilangan cacah siswa kelas V SD melalui pengarahan memahami masalah serta memberikan alasan dari setiap kali menaksir.

Penelitian bertujuan untuk memberikan pengalaman belajar mahasiswa Pendidikan Guru Sekolah Dasar (PGSD) dengan mengimplementasikan PBM untuk mengembangkan kemampuan komunikasi dan pemecahan masalah matematis mahasiswa PGSD. Masalah utama penelitian ini adalah: "Bagaimana kemampuan komunikasi, pemecahan masalah matematis mahasiswa PGSD setelah mengikuti Pembelajaran Berbasis Masalah (PBM)?". Beberapa pertanyaan penelitian yang dirinci dari rumusan masalah utama tersebut adalah sebagai berikut.

1. Apakah kemampuan komunikasi matematis dan kemampuan pemecahan masalah matematis mahasiswa yang mendapat PBM lebih baik dari kemampuan mahasiswa yang mendapat pembelajaran konvensional ditinjau secara keseluruhan dan pada tiap tingkat kemampuan awal matematis?

2. Adakah interaksi antara jenis pembelajaran dan tingkat kemampuan awal matematis masingmasing terhadap pencapaian kemampuan komunikasi dan pemecahan masalah matematis? 
3. Adakah asosiasi antara kemampuan komunikasi dan pemecahan masalah matematis mahasiswa?

Hipotesis penelitian ini adalah sebagai berikut.

1. Kemampuan komunikasi matematis mahasiswa yang mendapat PBM lebih baik daripada kemampuan mahasiswa yang mendapat pembelajaran konvensional ditinjau secara keseluruhan dan pada tiap kemampuan awal matematis.

2. Kemampuan pemecahan masalah matematis mahasiswa yang mendapat PBM lebih baik daripada kemampuan mahasiswa yang mendapat pembelajaran konvensional ditinjau secara keseluruhan dan pada tiap kemampuan awal matematis.

3. Terdapat interaksi antara jenis pembelajaran dan tingkat kemampuan awal matematis terhadap masing-masing kemampuan komunikasi dan pemecahan masalah matematis.

4. Terdapat asosiasi antara kemampuan komunikasi dan pemecahan masalah matematis mahasiswa.

Eksperimen berdisain postes kelompok kontrol sebagai berikut.

$$
\begin{array}{cc}
X & \text { Ruseffendi (1998) } \\
\hline &
\end{array}
$$

$\mathrm{X}$ adalah pembelajaran berbasis masalah dan $\mathrm{O}$ adalah tes komunikasi matematis dan tes pemecahan masalah matematis. Subyek penelitian dilakukan terhadap 67 orang mahasiswa PGSD pada satu Universitas Negeri di Bandung. Penetapan subyek dilakukan secara purposif yaitu mahasiswa yang sedang mengikuti perkuliahan Kapita Selekta Matematika. Instrumen penelitian menggunakan dua macam tes bentuk uraian yaitu tes komunikasi matematis dan tes pemecahaman masalah matematis. Kedua tes disusun dengan mengacu pada pedoman penyusunan tes yang memadai (Arikunto, 2008).

Sebelum eksperimen dilaksanakan kepada kedua kelompok mahasiswa (eksperimen dan kontrol) diberikan tes pemahaman matematika untuk mengukur kemampuan awal matematis mahasiswa (KAM). Tes disusun sebanyak 20 soal dalam bentuk pilihan ganda beralasan. Berdasarkan perbandingan hasil tes kemampuan awal dan skor ideal tes, mahasiswa terkelompok pada dua kelompok yaitu level sedang (11 orang) dan level kurang (57 orang). Pada akhir pembelajaran kedua kelas diberi tes komunikasi matematis dan tes pemecahan masalah matematis yang sama. Data penelitian dianalisis dengan ANOVA dua jalur untuk mengetahui pengaruh pembelajaran terhadap kemampuan komunikasi matematis, pemecahan masalah matematis. Sebelum dilakukan uji ANOVA, dilakukan uji prasyarat, yaitu uji normalitas distribusi data dan uji homogenitas variansi kelompok data; berturut-turut dengan uji Kolmogorov-Smirnov dan Levene. Dilakukan uji Mann-Whitney terhadap data yang tidak memenuhi syarat atau data sangat kecil. Untuk menguji asosiasi antar variabel penelitian digunakan uji chi-square. 
HASIL DAN PEMBAHASAN

1. Kemampuan Komunikasi Matematis Mahasiswa

Deskripsi kemampuan komunikasi matematis mahasiswa tercantum pada Tabel 1.

Tabel 1. Kemampuan Komunikasi Matematis Mahasiswa berdasarkan Pembelajaran dan Level Kemampuan Awal Matematis

\begin{tabular}{|c|c|c|c|c|c|c|c|}
\hline \multirow{3}{*}{$\begin{array}{l}\text { Kemampuan Awal } \\
\text { Matematis (KAM) }\end{array}$} & \multicolumn{6}{|c|}{ Kelompok Pembelajaran } & \multirow{3}{*}{$p$-value } \\
\hline & \multicolumn{2}{|c|}{ Berbasis Masalah } & \multicolumn{2}{|c|}{ Konvensional } & \multicolumn{2}{|c|}{ Total } & \\
\hline & $\bar{x}$ & SD & $\bar{x}$ & SD & $\bar{x}$ & SD & \\
\hline Sedang & 28,33 & 5,35 & 15,40 & 7,09 & 22,45 & 8,94 & $0,016^{*}$ \\
\hline Rendah & 20,21 & 7,60 & 10,57 & 4,57 & 15,39 & 7,89 & 0,000 \\
\hline Total & 21,65 & 7,84 & 11,30 & 5,20 & & & 0,000 \\
\hline$p$-value & \multicolumn{2}{|c|}{$0,009 *$} & \multicolumn{2}{|c|}{$0,066^{*}$} & \multicolumn{2}{|c|}{0,003} & \\
\hline
\end{tabular}

*Uji Mann-Whitney; skor ideal tes komunikasi matematis: 40

Berdasarkan data pada Tabel 1 diperoleh temuan sebagai berikut.

a) Secara keseluruhan kemampuan komunikasi matematis mahasiswa yang mengikuti PBM $(21,65)$ tergolong sedang dan lebih baik dari kemampuan mahasiswa kelas konvensional $(11,30)$ yang tergolong kurang dengan ( $p$-value $=0,000$ ).

b) Berdasarkan level KAM, pada tiap level yang sama kemampuan komunikasi matematis mahasiswa kelas PBM lebih baik dari kemampuan mahasiswa kelas konvensional. Pada level KAM sedang dengan uji Mann-Whitney ( $p$-value 0,016 ), dan pada level KAM rendah dengan ( $p$ value 0,000),

c) Pada kedua kelas (PBM dan konvensional), makin tinggi level KAM mahasiswa diperoleh makin tinggi pula kemampuan komunikasi matematis mahasiswa.

Kemampuan komunikasi matematis mahasiswa yang mendapat Pembelajaran Berbasis Masalah dan yang mendapat pembelajaran konvensional, tertera pada Gambar 1.

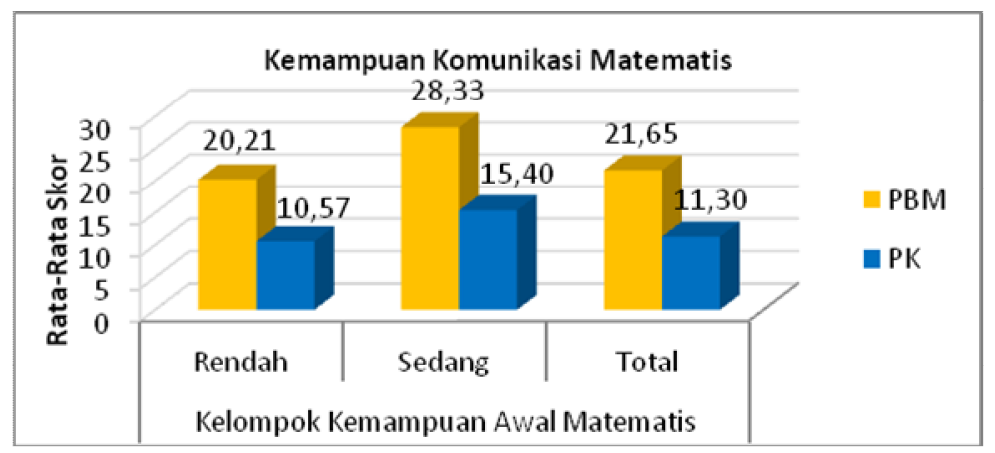

Gambar 1. Diagram kemampuan komunikasi matematis mahasiswa berdasarkan pembelajaran dan level KAM 


\section{Kemampuan Pemecahan Masalah Matematis Mahasiswa}

Deskripsi kemampuan pemecahan masalah matematis mahasiswa tercantum pada Tabel 2.

Tabel 2. Kemampuan Pemecahan Masalah Matematis Mahasiswa Berdasarkan Pembelajaran dan Level Kemampuan Awal Matematis

\begin{tabular}{|c|c|c|c|c|c|c|c|}
\hline \multirow{3}{*}{$\begin{array}{c}\text { Kemampuan Awal } \\
\text { Matematis }\end{array}$} & \multicolumn{6}{|c|}{ Kelompok Pembelajaran } & \multirow{3}{*}{$p$-value } \\
\hline & \multicolumn{2}{|c|}{ Berbasis Masalah } & \multicolumn{2}{|c|}{ Konvensional } & \multicolumn{2}{|c|}{ Total } & \\
\hline & $\bar{x}$ & SD & $\bar{x}$ & SD & $\bar{x}$ & SD & \\
\hline Sedang & 35,00 & 9,27 & 24,00 & 10,35 & 30,00 & 11,20 & $0,035^{*}$ \\
\hline Rendah & 25,46 & 10,65 & 12,89 & 4,79 & 19,18 & 10,35 & 0,000 \\
\hline Total & 27,15 & 10,93 & 14,58 & 7,15 & & & 0,000 \\
\hline$p$-value & \multicolumn{2}{|c|}{$0,037^{*}$} & \multicolumn{2}{|c|}{$0,019 *$} & \multicolumn{2}{|c|}{0,001} & \\
\hline
\end{tabular}

*Uji Mann-Whitney

Berdasarkan data pada Tabel 2. diperoleh temuan sebagai berikut.

a) Secara keseluruhan kemampuan pemecahan masalah matematis mahasiswa yang mengikuti PBM $(27,15)$ tergolong sedang dan lebih baik dari kemampuan mahasiswa kelas konvensional $(14,58)$ yang tergolong kurang dengan $(p$-value $=0,000)$.

b) Demikian pula ditinjau berdasarkan level (KAM), pada tiap level yang sama kemampuan pemecahan masalah matematis mahasiswa kelas PBM lebih baik dari kemampuan mahasiswa kelas konvensional. Pada level KAM sedang dengan ujin Mann-Whitney ( $p$-value 0,035), dan pada level KAM rendah dengan ( $p$-value 0,000),

c) Pada kedua kelas (PBM dan konvensional), makin tinggi level KAM mahasiswa diperoleh makin tinggi pula kemampuan pemecahan masalah matematis mahasiswa. Sedang pada kelas konvensional kemampuan pemecahan masalah matematis mahasiswa dengan KAM sedang dan KAM rendah berbeda secara signifikan ( $p$-value $=0,019$ ).

Kemampuan pemecahan masalah matematis mahasiswa yang mendapat Pembelajaran Berbasis Masalah dan yang mendapat pembelajaran konvensional, terltera pada Gambar 2.

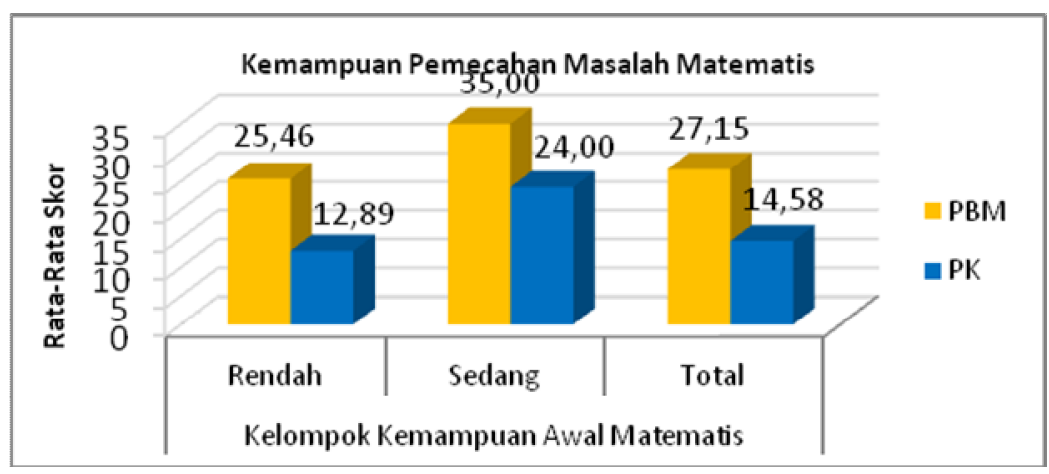

Gambar 2. Diagram kemampuan pemecahan masalah matematis mahasiswa berdasarkan pembelajaran dan level KAM 


\section{Kesulitan yang Dialami Mahasiswa dalam Mengembangkan Kemampuan Komunikasi dan Pemecahan Masalah Matematis}

Beberapa temuan tentang kesulitan mahasiswa dalam menyelesaikan soal tes komunikasi matematis yang diberikan diantaranya adalah: menyatakan suatu uraian atau paragraf matematis ke dalam gambar matematis, dan menunjukkan algoritma matematis dalam menyelesaikan masalah. Kesulitan tersebut mengakibatkan mahasiswa tidak mampu menyusun kalimat matematis dan algoritma matematis yang benar dalam menyelesaikan soal.

Kesulitan lainnya adalah dalam memeriksa kebenaran hasil yaitu kemampuan menginterpretasikan hasil sesuai permasalahan asal. Mahasiswa tidak dapat menunjukkan interpretasi hasil sesuai permasalahan asal, atau menunjukkan cara lain dalam menemukan jawaban.

\section{Interaksi antara Pembelajaran dan Tingkat Kemampuan Awal Matematis terhadap Pencapaian Kemampuan Komunikasi dan Pemecahan Masalah Matematis}

Rangkuman hasil pengujian eksistensi interaksi pembelajaran dan tingkat kemampuan awal matematika terhadap pencapaian kemampuan komunikasi dan pemecahan masalah matematis terlihat pada Tabel 3.

Tabel 3. Hasil Pengujian Interaksi Pembelajaran dengan Tingkat Kemampuan Awal Matematik terhadap Kemampuan Komunikasi dan Pemecahan Masalah Matematis.

\begin{tabular}{lccc}
\hline \multicolumn{1}{c}{ Variabel } & $\mathrm{F}$ & $p$-value & $\mathrm{H}_{0}$ \\
\hline Komunikasi Matematis & 0,630 & 0,430 & Terima \\
$\begin{array}{lcc}\text { Pemecahan Masalah Matematis } \\
\begin{array}{l}\text { Disposisi terhadap PBM } \\
\text { (untuk kelas eksperimen) }\end{array}\end{array}$ & 0,077 & 0,782 & Terima \\
\hline
\end{tabular}

$\mathrm{H}_{0}$ : Tidak terdapat interaksi pembelajaran dan kemampuan awal terhadap pengembangan kemampuan matematis

Pada tiap variabel diperoleh $p$-value lebih dari $\alpha=0,05$ yang berarti $\mathrm{H}_{0}$ diterima. Dengan demikian tidak terdapat interaksi yang signifikan antara pembelajaran dan tingkat kemampuan awal matematis mahasiswa terhadap pencapaian kemampuan komunikasi dan pemecahan masalah matematis. Demikian pula untuk kelas eksperimen, tidak terdapat interaksi yang signifikan antara pembelajaran dan tingkat kemampuan awal matematis mahasiswa terhadap pencapaian disposisi terhadap PBM mahasiswa.

Diagram interaksi terlukis pada Gambar 3 dan 4. 


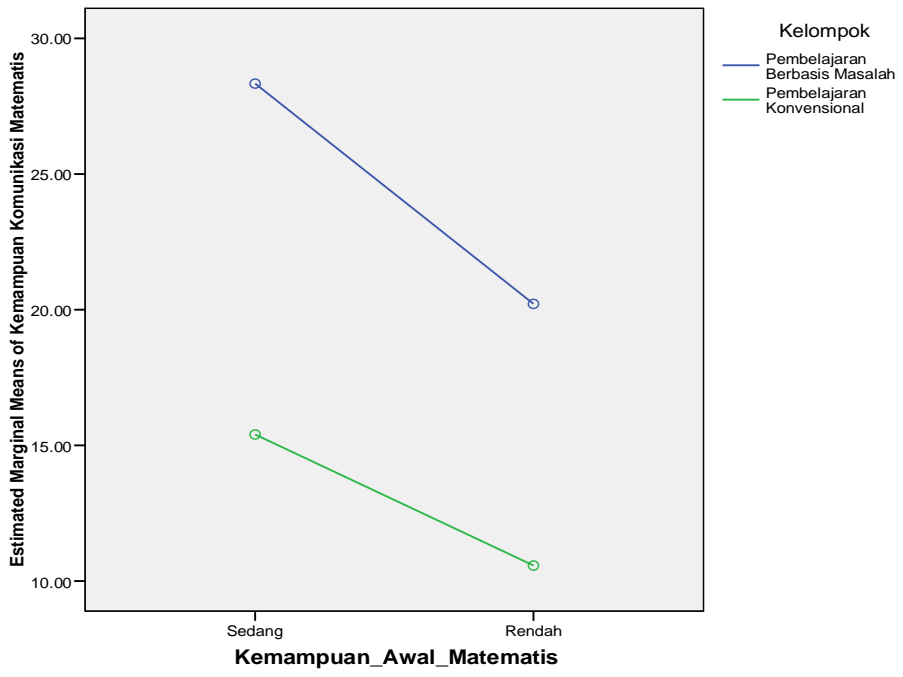

Gambar 3. Diagram Interaksi antara pembelajaran dan tingkat KAM terhadap komunikasi matematis

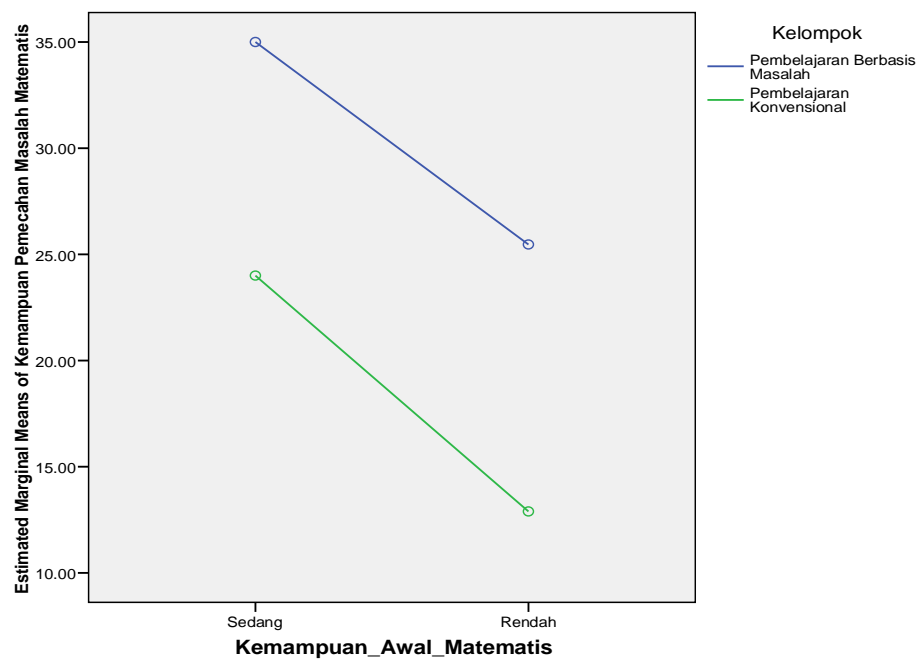

Gambar 4. Diagram interaksi antara pembelajaran dan tingkat KAM terhadap pemecahan masalah matematis

5. Asosiasi antara Kemampuan Komunikasi dan Pemecahan Masalah Matematis Mahasiswa Assosiasi antara kemampuan komunikasi dan pemecahan masalah matematis diuji melalui tabel kontingensi dengan pengujian menggunakan chi-square test. Pengujian asosiasi tersebut terlukis dalam Tabel 4. 
Tabel 4. Asosiasi antara Kemampuan Komunikasi dengan Kemampuan Pemecahan Masalah Matematis

\begin{tabular}{|c|c|c|c|c|c|}
\hline \multirow{2}{*}{$\begin{array}{c}\text { Kemampuan } \\
\text { Komunikasi Matematis }\end{array}$} & \multicolumn{3}{|c|}{$\begin{array}{c}\text { Kemampuan Pemecahan } \\
\text { Masalah Matematis }\end{array}$} & \multirow[t]{2}{*}{ Total } & \multirow[t]{2}{*}{$p$-value } \\
\hline & Tinggi & Sedang & Rendah & & \\
\hline Tinggi & $\begin{array}{c}4 \\
(66,7 \%)\end{array}$ & $\begin{array}{c}2 \\
(33,3 \%)\end{array}$ & $\begin{array}{c}0 \\
(0,0 \%)\end{array}$ & $\begin{array}{c}6 \\
(100 \%)\end{array}$ & \multirow{4}{*}{0,000} \\
\hline Sedang & $\begin{array}{c}8 \\
(22,9 \%)\end{array}$ & $\begin{array}{c}19 \\
(54,3 \%)\end{array}$ & $\begin{array}{c}8 \\
(22,9 \%)\end{array}$ & $\begin{array}{c}35 \\
(100 \%)\end{array}$ & \\
\hline Rendah & $\begin{array}{c}2 \\
(7,7 \%)\end{array}$ & $\begin{array}{c}5 \\
(19,2 \%)\end{array}$ & $\begin{array}{c}19 \\
(73,1 \%)\end{array}$ & $\begin{array}{c}26 \\
(100 \%)\end{array}$ & \\
\hline Total & $\begin{array}{c}14 \\
(20,9 \%)\end{array}$ & $\begin{array}{c}26 \\
(38,8 \%)\end{array}$ & $\begin{array}{c}27 \\
(40,3 \%)\end{array}$ & $\begin{array}{c}67 \\
(100 \%)\end{array}$ & \\
\hline
\end{tabular}

Tabulasi silang antara kemampuan komunikasi matematis dengan kemampuan pemecahan masalah matematis menunjukkan bahwa mayoritas responden dengan kemampuan komunikasi matematis kategori tinggi $(66,7 \%)$ memiliki kemampuan pemecahan masalah matematis kategori tinggi. Kemudian, responden dengan kemampuan komunikasi matematis kategori sedang $(54,3 \%)$ memiliki kemampuan pemecahan masalah matematis kategori sedang. Begitu pula responden dengan kemampuan komunikasi matematis kategori rendah $(73,1 \%)$ memiliki kemampuan pemecahan masalah matematis kategori rendah.

Hasil uji statistik menunjukkan bahwa pada tingkat kepercayaan 95\% teruji adanya assosiasi yang signifikan antara kemampuan komunikasi matematis dengan kemampuan pemecahan masalah matematis. Hal ini tercermin dari nilai $X^{2}=25,02$ dengan indeks kontigensi sebesar $C=0,521$

\section{KESIMPULAN DAN SARAN}

Kemampuan komunikasi matematis mahasiswa yang mendapat Pembelajaran Berbasis Masalah ditinjau secara keseluruhan dan pada tiap tingkat kemampuan awal matematis mahasiswa tergolong pada klasifikasi sedang dan ini lebih baik dari kemampuan matematis mahasiswa pada kelas konvensional. Kesimpulan serupa terjadi untuk kemampuan pemecahan masalah matematis mahasiswa. Penelitian menunjukkan bahwa tidak terdapat interaksi antara pembelajaran dan tingkat kemampuan awal matematis (sedang, rendah) mahasiswa terhadap kemampuan komunikasi dan terhadap pemecahan masalah matematis. Selain itu pada kelas eksperimen terdapat asosiasi antara kemampuan komunikasi, dan pemecahan masalah matematis mahasiswa.

Kesimpulan yang telah dikemukakan, memberikan implikasi sebagai berikut.

1. Hasil secara keseluruhan maupun pada tiap tingkat kemampuan awal matematis mahasiswa, menunjukkan kemampuan komunikasi dan pemecahan masalah matematis mahasiswa yang memperoleh pembelajaran berbasis masalah masih tergolong sedang. Namun demikian, kemampuan yang didapatkan melalui pembelajaran berbasis masalah lebih unggul dibandingkan pembelajaran konvensional. Dalam penelitian ini kemampuan awal matematis mahasiswa sebagian besar masih tergolong kurang. Semakin tinggi kemampuan awal matematis mahasiswa semakin tinggi pula kemampuan komunikasi dan pemecahan masalah matematis mahasiswa. Ini berarti kemampuan awal matematis memberi peran terhadap pencapaian kedua kemampuan 
matematis tersebut. Implikasi dari analisis tersebut adalah, pembelajaran berbasis masalah dalam perkuliahan matematika di PGSD dapat dijadikan alternatif pendekatan pembelajaran yang disertai dengan upaya meningkatkan kemampuan awal mahasiswa lebih dahulu terutama untuk pemahaman materi dan kemampuan prasyarat.

2. Asosiasi yang cukup tinggi antara kemampuan komunikasi dan pemecahan masalah matematis memberi implikasi bahwa pengembangan kemampuan komunikasi matematis saling menunjang dengan pengembangan kemampuan pemecahan masalah matematis.

\section{REFERENSI}

Akinsola, M.K. (2008). Relationship of some psychological variables in predicting problem solving ability of in-service mathematics teachers. The Montana Mathematics Enthusiast, 5(1), 79 100.

Arikunto, S. (2008). Dasar-dasar evaluasi pendidikan (Edisi Revisi). Jogja: Bumi Aksara.

Boud, D. \& Felleti (1997). The challenge of problem-based learning. London: Kogapage.

Departemen Pendidikan Nasional. (2006). Kurikulum Tingkat Satuan Pendidikan. Jakarta: Badan Standar Nasional Pendidikan.

Departemen Pendidikan Tinggi. (2006). Rambu-rambu Penyelenggaraan Pendidikan Profesional Guru Sekolah Dasar.

Duch, B.J., Groh, S.E., \& Allen, D.E. (2001). Why problem-based learning?. The power of problembased learning. Virginia: Stylus Publishing.

Kusmini. (2005). Model pembelajaran berbasis masalah untuk mengembangkan kecakapan matematika siswa SD kelas V sebagai implementasi kurikulum berbasis kompetensi (KBK). Skripsi yang tidak dipublikasikan. Universitas Negeri Semarang.

Nasrun, H. (2008). Meningkatkan kemampuan estimasi pada penjumlahan bilangan cacah melalui pembelajaran berbasis masalah pada siswa kelas V SD. Disertasi yang tidak dipublikasikan. Program Pasacasarjana Universitas Negeri Malang.

Ruseffendi, E.T. (1998). Dasar-dasar penelitian pendidikan dan bidang non-eksakta lainnya. IKIP Semarang Press.

Saptono, R. (2003). Is problem based learning (PBL) a better approach for engineering education? CAFEO-21 (21st Conference of the Asian Federation of Engineering Organization), 22-23 October 2003, Yogyakarta.

Sumarmo, U. (2006). Berpikir matematik tingkat tinggi: Apa, mengapa, dan bagaimana dikembangkan pada siswa sekolah menengah dan mahasiswa calon guru. Makalah disajikan pada Seminar Pendidikan Matematika di Jurusan Matematika FPMIPA Universitas Pajajaran Tanggal 22 April 2006: tidak diterbitkan.

Sumarmo, U. (2010). Berpikir dan disposisi matematik: Apa, mengapa, dan bagaimana dikembangkan pada peserta didik. FPMIPA UPI: tidak diterbitkan.

Suradijono, SHR. (2004). Problem-based learning: Apa dan bagaimana? Makalah Seminar. Penumbuhan Inovasi Sistem Pembelajaran: Pendekatan Problem-Based Learning berbasis ICT (Information and Communication Technology), 15/5/2004, Yogyakarta. 


\section{Lampiran 1}

\section{Contoh Instrumen}

Sebagai ilustrasi berikut ini disajikan sampel instrumen yang diberikan pada penelitian ini.

\section{Contoh butir tes komunikasi matematis:}

Seseorang akan mengecat tembok rumah yang tingginya 4,5 m dengan menggunakan sapuan kuas biasa. Alat lainnya adalah tangga bambu. Panjang tangga bambu yang digunakan adalah 3,5 m. Posisi tangga disimpan pada tembok rumah dengan jarak ujung pijakan tangga dan lantai $210 \mathrm{~cm}$. Tinggi orang tersebut $160 \mathrm{~cm}$.

a) Tunjukkan gambar geometris dari soal tersebut.

b) Tulis kalimat matematika untuk mengetahui tinggi tembok yang mudah di cat.

c) Tunjukkan perhitungan untuk menentukan posisi tangga yang memudahkan mengecat tembok sampai ketinggian 4,5 m.

d) Gambarkan posisi tangga yang dimaksud oleh c).

\section{Contoh butir tes pemecahan masalah matematis:}

Pak Agus memiliki kebun berbentuk persegipanjang. Luasnya $1575 \mathrm{~m}^{2}$ dan kelilingnya $160 \mathrm{~m}$. Kebun tersebut telah terjual, sekarang akan membeli kolam seluas kebun yang terjual.

a) Apakah soal memiliki cukup data untuk menentukan bangun yang luasnya sama? Jelaskan.

b) Tulis kalimat matematika yang dapat membantu menemukan ukuran kolam yang akan dibeli?

c) Tuliskan langkah dan hasil penyelesaian menentukan ukuran kolam.

Periksa apakah jawaban Anda benar! 